Pedagogik Jurnal Pendidikan, Maret 2017, Volume 12 Nomor 1 , (27-33)

\title{
Peningkatan Hasil Belajar IPA Dengan Menggunakan Strategi Pembelajaran Learning Start With A Question
}

\author{
Oleh : Agung Pribadi *
}

\begin{abstract}
Abstrak
Penelitian ini bertujuan untuk: (1) mengetahui aktivitas peserta didik dalam kegiatan belajar mengajar dengan menggunakan strategi Learning Start With A Question, (2) mengetahui peningkatan hasil belajar IPA pada peserta didik kelas Iva SDS Muhammadiyah Selat Kuala Kapuas setelah menggunakan strategi Learning Start With A Question.

Jenis penelitian yang digunakan peneliti adalah penelitian Tindakan kelas (PTK) yang berusaha memecahkan permasalahan yang dihadapi pada situasi sekarang. Subjek dalam penelitian ini berjumlah 27 orang peserta didik, 16 orang laki-laki dan 11 orang perempuan. Teknik analisis data didasarkan pada hasil siklus dari tiap proses pembelajaran.

Hasil penelitian ini menunjukan bahwa : (1) Aktivitas peserta didik menggunakan strategi Learning Start With A Question lebih baik dan mengalami peningkatan disetiap siklus. Pada siklus I peserta didik memperoleh nilai dengan rata - rata 3,08 dengan kategori baik, dan siklus II peserta didik memperoleh nilai dengan rata - rata 3,75 dengan kategori baik (2) ada peningkatan hasil belajar IPA melalui penggunaan strategi Learning Start With A Question yang menunjukan dari hasil belajar pada pra tindakan diperoleh rata - rata 37,59, pada siklus I diperoleh rata - rata 58,33 dan pada siklus II diperoleh rata - rata 81,11 dengan ketuntasan klasikal yaitu $100 \%$.
\end{abstract}

\section{Kata Kunci: Hasil Belajar, Pembelajaran, Start With A Qurstion}

\section{PENDAHULUAN}

Dalam Undang-undang No 20 Tahun 2003 Pasal 3 dijelaskan bahwa Pendidikan Nasional berfungsi mengembangkan kemampuan dan membentuk watak serta peradaban bangsa yang bermartabat dalam rangka mencerdaskan kehidupan bangsa, bertujuan untuk berkembangnya potensi peserta didik, agar menjadi manusia yang beriman dan bertakwa kepada Tuhan Yang maha Esa, berahlak mulia serta, berilmu, cakap, kreatif , mandiri, dan menjadi warga Negara yang demokratis serta bertanggung jawab. Rumusan tujuan pendidikan diatas, sarat dengan pembentukan sikap. Dengan demikian, tidaklah lengkap manakala dalam strategi pembelajaran tidak membahas strategi pembelajaran yang berhubungan dengan pembentukan sikap dan nilai (Wina Sanjaya:2008, 273).

IPA diperlukan dalam kehidupan seharihari untuk memenuhi kebutuhan manusia melalui pemecahan masalah-masalah yang dapat diidentifikasikan. Penerapan IPA perlu dilakukan secara bijaksana agar tidak berdampak buruk padalingkungan. Pembelajaran IPA sebaiknya dilakukan secara inkuiri (inquiry) untuk menumbuhkan kemampuan berpikir, bekerja dan bersikap ilmiah serta mengkomunikasikannya sebagai aspek penting kecakapan hidup. Oleh karena itu pembelajaran IPA di SD/MI menekankan pada pemberian pengalaman belajar secara langsung melalui penggunaan dan pengembangan keterampilan proses dan sikap ilmiah. (Depdiknas, 2007 : 484).

Dari tujuan tersebut maka tugas seorang pendidik adalah bagaimana menerapkan beberapa ketrampilan mengajar agar seluruh tujuan tersebut dapat tercapai dalam mata pelajaran IPA. Selain itu, pembelajaran IPA juga memberikan pengetahuan dasar dari konsep yang bermanfaat untuk kehidupan sehari-hari.

Tujuan yang terkandung dalam KTSP 
tersebut sudah mengandung ide-ide yang dapat mengantisipasi perkembangan IPTEK secara global. Namun kenyataan dilapangan tidak sejalan dengan tujuan pada kurikulum, seperti temuan di lapangan tentang pembelajaran IPA di sekolah dasar antara lain, guru belum melaksanakan pembelajaran yang dapat menumbuhkan kemampuan berfikir, kerja dan bersikap ilmiah bagi peserta didik dalam pembelajarannya guru memberikan siswa dengan sejumlah konsep yang bersifat hafalan belaka. Dengan demikian, siswa tidak memahami dasar kualitatif tentang fakta-fakta dalam materi serta tingkat pemahaman semakin berkurang sehingga pada kenyataanya timbul kebosanan pada siswa, tujuan siswa agar menguasai konsep yang diajarkan justru tidak tercapai. Kondisi seperti itu ditemukan juga pada pembelajaran IPA, yaitu guru berusaha agar siswa mampu menghafal materi sebanyak mungkin sesuai yang diterangkan oleh guru.

Pembelajaran juga cenderung bersifat hafalan. Hal ini terlihat bahwa dalam kegiatan pembelajaran peserta didik hanya menghafal materi tanpa melihat dan mengalami langsung dari konsep materi yang dipelajari tersebut. Selain itu, kegiatan praktek sangat jarang sekali dilakukan, pembelajaran juga cenderung dilaksanakan di dalam kelas, tidak pernah belajar langsung di lingkungan terbuka.

Peserta didik juga terlihat kurang bersemangat dalam belajar. Sebagian besar peserta didik mengantuk dan kurang bergairah saat belajar, bahkan ada sebagian peserta didik yang tidak mau menulis. Selain itu, ada juga beberapa orang peserta didik yang terlihat lesu dan kurang memperhatikan penjelasan guru. Jika diberikan tugas, ada beberapa orang peserta didik yang tidak mau mengerjakan tugas tersebut. guru diharapkan mampu menciptakan suatu pembelajaran yang bisa menumbuhkan minat dan motivasi bagi siswa, menumbuhkan rasa percaya diri siswa agar siswa berani mengeluarkan pendapatnya, dan berani bertanya apabila ada materi yang belum mereka pahami, serta siswa terbiasa membaca secara intensif. Selain itu, dalam pembelajaran yang akan dilaksanakan untuk mengatasi permasalahan di atas, guru harus menggunakan berbagai sumber belajar agar memperkaya pengetahuan siswa, guru diharapkan menggunakan Strategi pembelajaran yang inovatif.

Pembelajaran IPA idealnya diajarkan sesuai dengan taraf berpikir peserta didik. Strategi, Model dan Metode yang digunakan hendaknya bersifat sistematis dapat memotivasi peserta didik untuk berperan aktif dalam pembelajaran IPA sehingga pembelajaran menjadi mudah dan menyenangkan. Untuk mengatasi permasalahn yang telah dijelaskan tadi, maka peneliti menawarkan strategi pembelajaran yang menarik, mudah dan sederhana yaitu strategi pembelajaran LSQ (Learning Start With A Question).

Strategi Pembelajaran Learning Start With A Question (LSQ) adalah suatu strategi pembelajaran aktif dalam bertanya. Agar siswa aktif dapat bertanya, maka siswa diminta untuk mempelajari materi yang akan dipelajarinya, yaitu dengan membaca terlebih dahulu (Zaini, dkk, (Fitria Widyaningsih, 2013;51)).

\section{STUDI LITERATUR}

Menurut R. Gagne (Ahmad Susanto, 2012;1), belajar dapat didefinisikan sebagai suatu proses di mana suatu organisme berubahperilakunya sebagai akibat pengalaman. Belajar dan mengajar merupakan dua konsep yang tidak dapat dipisahkan satu sama lain. Dua konsep ini menjadi terpadu dalam suatu kegiatan dimana menjadi interaksi antara guru dengan siswa, serta siswa dengan siswa pada saat pembelajaran berlangsung.

Menurut hamalik (Ahmad Susanto, 2012;3) menjelaskan bahwa belajar adalah memodifikasi atau memperteguh prilaku melalui pengalaman (learning is defined as the modificator or strngthening of behavior through experiencing). Menurut pengertian ini, belajar merupakan suatu proses, suatu kegiatan, dan bukan merupakan suatu hasil atau tujuan. Dengan demikian, belajar itu 
bukan sekedar mengingat atau menghafal saja namun lebih luas dari itu merupakan mengalami. Hamalik juga menegaskan bahwa belajar adalah suatu proses perubahan tingkah laku individu atau seseorang melalui interaksi dengan lingkungannya. Perubahan tingkah laku ini mencakup perubahan dalam kebiasaan (hebit), sikap (afektif), dan keterampilan (psikomotorik). Perubahan tingkah laku dalam kegiatan belajar disebabkan oleh pengalaman atau latihan.

Dari beberapa pengertian belajar di atas dapat disimpulkan bahwa belajar adalah suatu aktivitas yang dilakukan seseorang dengan sengaja dalam keadaan sadar untuk memperoleh suatu konsep, pemahaman, atau pengetahuan baru sehingga memungkinkan seseorang terjadinya perubahan prilaku yang relatif tetap baik dalam berpikir, merasa, maupun dalam bertindak.

Dimyanti dan Mudjiono (2015:37) "Hasil belajar merupakan hasil dari suatu interaksi tindak belajar dan tindak mengajar". Sedangkan menurut Nawawi (dalam Ahmad Susanto 2012:5) "Hasil belajar diartikan sebagai tingkat keberhasilan siswa dalam mempelajari materi pelajaran di sekolah yang dinyatakan dalam skor yang diperoleh dari hasil tes mengenal sejumlah materi pelajaran tertentu".

Dari kutipan diatas dapat disimpulkan bahwa hasil belajar merupakan suatu proses belajar mengajar yang ditandai dengan adanya perubahan tingkah laku, pengetahuan, keterampilan dan kemampuan yang dimiliki peserta didik itu sendiri setelah ia menerima serta melakukan aktivitas belajar dan adanya interaksi dari tindak belajar dan tindak mengajar.

Kata "IPA" merupakan singkatan kata "Ilmu Pengetahuan Alam" . Kata-kata "Ilmu Pengetahuan Alam" merupakan terjemahan dari kata-kata Bahasa Inggris" Natural Science" secara singkat sering disebut "Science". Natural artinya alamiah, berhubungan dengan alam atau bersangkut paut dengan alam. Science artinya ilmu pengetahuan. Jadi Ilmu Pengetahuan Alam (IPA) atau science itu secara harfiah dapat disebut sebagai ilmu tentang alam ini. Ilmu yang mempelajari peristiwa-peristiwa yang terjadi di alam. Untuk selanjutnya kita akan menggunakan kata IPA sebagai suatu istilah. Iskandar. Srini M, (Bahrudin Ardi, 2013;14).

Sains merupakan ilmu empirik yang membahas tentang fakta dan gejala alam maka dalam pembelajarannya harus factual, artinya tidak hanya secara verbal sebagaimana terjadi pada pembelajaran secara tradisional. Asyari, Muslichah, (Bahrudin Ardi, 2013;14). Pembelajaran adalah upaya untuk membelajarkan siswa. Dalam definisi ini terkandung makna bahwa dalam pembelajaran ada kegiatan memilih, menetapkan, dan mengembangkan metode atau strategi yang optimal untuk mencapai hasil pembelajaran yang diinginkan (Degeng, dalam Heni Mularsih, 2010;67). Metode pembelajaran mengacu pada cara yang digunakan dalam kondisi tertentu untuk mencapai hasil pembelajaran yang diinginkan, sedangkan strategi pembelajaran mengacu pada penataan caracara memilih, menetapkan, dan mengembangkan strategi pembelajaran sehingga terwujud suatu urutan langkah yang prosedural yang dapat dipakai untuk mencapai hasil yang diinginkan (Degeng dalam Heni Mularsih, 2010;67).

Strategi pembelajaran adalah rencana dalam rangka membantu siswa dalam usaha belajarnya untuk mencapai setiap tujuan belajarnya. Dalam hal ini, guru dapat menggunakan bahan ajar atau satu unit produksi sebagai media pembelajaran (Gagne dkk, dalam Heni Mularsih, 2010;67).

Strategi Pembelajaran Learning Start With A Question (LSQ) adalah suatu strategi pembelajaran aktif dalam bertanya. Agar siswa aktif dapat bertanya, maka siswa diminta untuk mempelajari materi yang akan dipelajarinya, yaitu dengan membaca terlebih dahulu (Zaini, dkk, (Fitria Widyaningsih, 2013;51)).

Learning Start With a Question (LSQ) termasuk salah satu metode pembelajaran aktif. Hakekat metode pembelajaran aktif adalah untuk mengarahkan atensi peserta 
didik terhadap materi yang dipelajarinya (Suprijono dalam Fitria Widyaningsih, 2013;51).

Selanjutnya, Munthe (dalam Fitria Widyaningsih, 2013;51) menyatakan bahwa strategi pembelajaran aktif adalah satu alternatif yang memungkinkan peserta didik melakukan kontekstualisasi guna menciptakan partisipasi dan keterlibatan aktif mereka dalam proses pembelajaran.

\section{METODOLOGI}

Penelitian ini dilakukan di SDS Muhammadiyah Selat yang terletak di Jl. Barito Komplek Perguruan Muhammadiyah. Alasan mengadakan penelitian di SDS Muhammadiyah Selat karena di SD ini terdapat permasalahan pembelajaran yang perlu untuk diteliti salah satunya yaitu rendahnya hasil belajar Ilmu Pengetahuan Alam (IPA) di sekolah ini.

Penelitian ini merupakan Penelitian Tindakan Kelas (PTK) yang dikategorikan penelitian yang berusaha untuk memecahkan atau menjawab permasalahan yang dihadapi oleh situasi tertentu.

Menurut Arikunto (Jasman Jalil, 2014;6) PTK adalah gabungan pengertian dari kata penelitian tindakan, dan kelas. Penelitian adalah kegiatan mengamati suatu objek, dengan menggunakan kaidah metodologi tertentu untuk mendapatkan data yang bermanfaat bagi penelitian dan orang lain demi kepentingan bersama.Suatu penelitian akan menghasilkan kesimpulan yang tepat, apabila menggunakan jenis penelitian yang tepat dan benar sesuai dengan masalah yang diteliti, situasi, dan kondisi saat penelitian tersebut dilakukan.

Menurut Suaidin (Jasman Jalil, 2014;6) PTK didefinisikan sebagai suatu bentuk kajian reflektif oleh guru sebagai pelaku tindakan yang bertujuan untuk meningkatkan kemampuan rasional dalam melaksanakan tugas keguruannya, memperdalam pemahaman terhadap tindakan yang dilakukannya, serta memperbaiki pembelajaran yang dilakukan.

Menurut Stephan Kemmis yang dikutip oleh Saminato (Jasman Jalil, 2014;6) bahwa PTK adalah bentuk kajian reflektif oleh pelaku tindakan yang dilakukan untuk meningkatkan kemantapan rasional dari tindakan mereka dalam melaksanakan tugas memperdalam pemahaman terhadap tindakan yang dilakukannya, memperbaiki kondisi dimana praktik-praktik pembelajaran tersebut dilakukan, serta dilakukan secara kolaboratif.

Berdasarkan pendapat di atas, maka disimpulkan bahwa penelitian tindakan kelas adalah suatu proses kegiatan pembelajaran yang mengamati peserta didik mengenai penggunaan alat peraga yang dlakukan guru untuk meningkatkan hasil belajar peserta didik.

Dalam pelaksanaan penelitian tindakan kelas ini yang menjadi subjek penelitian adalah peserta didik kelas IVa semester ganjil yang berjumlah 27 orang. Terdiri dari 11 peserta didik perempuan dan 16 peserta didik laki-laki. Sedangkan yang menjadi objek penelitian adalah hasil belajar IPA.

Data yang dikumpulkan dari setiap siklus akan dianalisis menggunakan metode Mixed Methods atau metode kombinasi antara kualitatif dan kuantitatif. Creswell (Sugiyono, 2013) menyatakan bahwa "Metode penelitian kombinasi (mixed method) akan berguna bila metode kuantitatif atau metode kualitatif secara sendiri - sendiri tidak cukup akurat digunakan untuk memahami permasalahan penelitian atau dengan menggunakan metode kualitatif dan kuantitatif secara kombinasi akan dapat memperoleh pemahaman yang paling baik sehingga diperoleh data yang lebih komprehensif, valid, reliable dan obyektif.

\section{HASIL DAN PEMBAHASAN}

Hasil perhitungan nilai rata-rata dan ketuntasan hasil belajar didapat dari hasil tes awal peserta didik kelas IVa SDS Muhammadiyah Selat didapat nilai rata-rata 37,59 dan ketuntasan belajar sebesar $0 \%$.

Dari data yang dipaparkan pada tabel 7 diperoleh gambaran bahwa dengan demikian dapat disimpulkan ketuntasan belajar peserta didik pada materi Panca Indra dan Fungsinya pada Mata Pelajaran IPA masih dibawah standar ketuntasan 
minimal atau belum tuntas, $100 \%$ peserta didik yang memperoleh nilai tidak tuntas.

Pembelajaran dapat dikatakan tuntas apabila persentase dalam evaluasi pembelajaran mencapai $85 \%$ dan memperoleh nilai rata-rata 65. Atas dasar data awal inilah, peneliti merasa perlu melakukan tindakan kelas dalam dua siklus untuk pembelajaran IPA menggunakan strategi pembelajaran Learning Start With A Question untuk meningkatkan hasil belajar IPA pada peserta didik.

Berdasarkan hasil perhitungan rata - rata, maka dapat dilihat hasil nilai rata - rata peserta didik pada tes siklus 1 adalah 58,33.

Menghitung ketuntasan belajar peserta didik secara klasikal, dimana indikator ketuntasan belajar yang ditentukan KKM 65 ketuntasan klasikal

$$
\begin{aligned}
\mathrm{TB} & =\frac{\sum s 2^{65}}{n} \times 100 \% \\
& =\frac{12}{27} \times 100 \% \\
& =0,44 \times 100 \% \\
& =44,44 \%
\end{aligned}
$$

Berdasarkan hasil perhitungan ketuntasan hasil belajar, maka dapat dilihat ketuntasan hasil belajar peserta didik pada tes awal siklus 1 adalah 44,44\%.

Menghitung nilai rata - rata, untuk mengetahui pencapaian nilai ketuntasan minimal peserta didik dengan membagi jumlah nilai seluruh peserta didik dengan jumlah seluruh peserta didik dengan rumus :

$$
\mathrm{M}=\frac{\sum x}{N}=\frac{2190}{27}=81,11
$$

Berdasarkan hasil perhitungan rata - rata, maka dapat dilihat hasil nilai rata - rata peserta didik pada tes siklus 2 adalah 81,11.

Menghitung ketuntasan belajar peserta didik secara klasikal, dimana indikator ketuntasan belajar yang ditentukan KKM 65 ketuntasan klasikal adalah $85 \%$.

$$
\begin{aligned}
\text { TB } & =\frac{z_{s} z^{65}}{n} \times 100 \% \\
& =\frac{27}{27} \times 100 \% \\
& =1 \times 100 \% \\
& =100 \%
\end{aligned}
$$

Berdasarkan hasil perhitungan ketuntasan hasil belajar, maka dapat dilihat ketuntasan hasil belajar peserta didik pada tes awal siklus 2 adalah $100 \%$.

Melalui pembelajaran menggunakan strategi Learning Start Whit a Quetion oleh peneliti di kelas IVa SDS Muhammadiyah Selat Kuala Kapuas aktivitas guru dan peserta didik menunjukan suatu peningkatan yang baik. Aktivitas guru pada siklus I memperoleh nilai rata -rata 3,39. Sedangkan pada siklus II ada peningkatan menjadi lebih baik, dengan penilaian rata rata oleh pengamat sebesar 3,67. Dan aktivitas peserta didik pada siklus I nilai rata-rata 3,08 pada siklus II meningkat menjadi 3,75 .

Adapun peningkatan aktivitas guru dan peserta didik dapat dilihat dalam gambar diagram berikut :

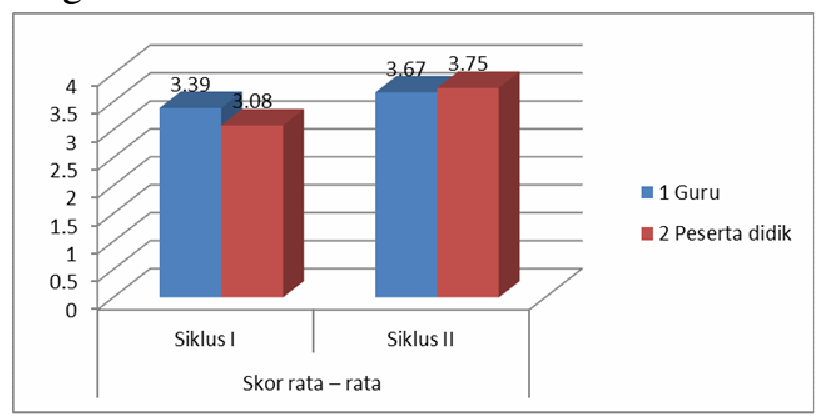


Pada pre tes belum memuaskan karena $0 \%$ peserta didik yang mengalami ketuntasan belajar, pada siklus I persentase ketuntasan belajar peserta didik menagalami peningkatan namun belum mencapai indikator ketuntasan $85 \%$ yang hanya hanya mendapat $44,44 \%$ dan mendapat nilai rata - rata 58,33. Pada siklus II nilai peserta didik mengalami peningkatan sangat bagus dengan perolehan nilai rata - rata 81,11 dengan kriteria ketuntasan secara klasikal mencapai $100 \%$. Peneliti menganggap pada siklus II ini sudah berhasil karena telah mencapai nilai KKM dan telah berhasil mencapai nilai ketuntasan secara klasikal.

Adapun peningkatan hasil belajar dapat dilihat dalam gambar diagram berikut :

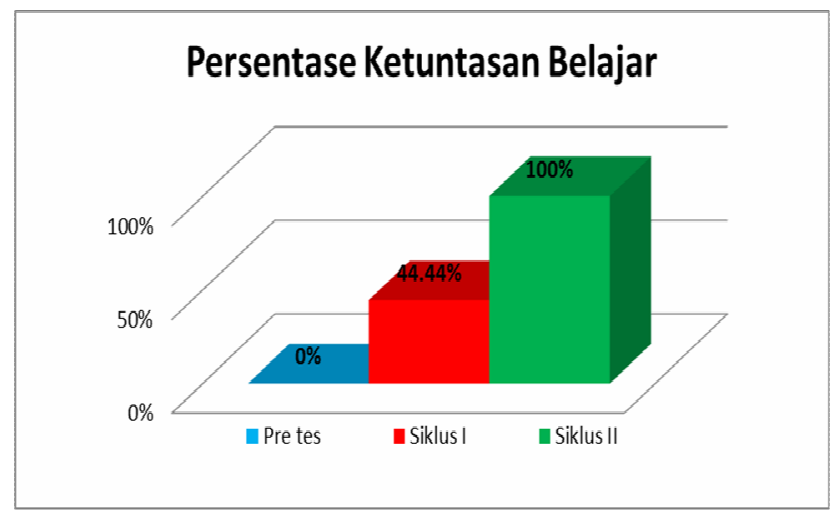

Berdasarkan hasil penelitian diatas maka hasil belajar peserta didik pada materi Alat Indra dan Fungsinya dengan menggunakan Strategi Learning Start Whit a Quetion dapat membantu meningkatkan hasil belajar IPA peserta didik.

\section{SIMPULAN}

1. Aktivitas belajar IPA lebih baik dengan menggunakan strategi pembelajaran Learning Start With A Question pada materi ajar Panca Indra dan Fungsinya di SDS Muhammadiyah Selat kelas IVa Tahun Ajaran 2015/2016. Hal tersebut terlihat pada aktivitas peserta didik pada Siklus I dengan kategori baik dengan skor rata-rata 3,08 dan pada siklus II ada peningkatan skor rata-rata 3,75 dengan kategori baik.

2. Ada peningkatan hasil belajar IPA Dengan Menggunakan Strategi Pembelajaran Learning Start With A Question pada materi ajar Panca Indra dan Fungsinya di SDS Muhammadiyah Selat kelas IVa Tahun Ajaran 2015/2016. Rata - rata pada pre tes mendapat hasil 37,59 dengan persentase ketuntasan klasikal $0 \%$. Pada siklus I diperoleh hasil rata - rata 58,33 dengan persentase ketuntasan klasikal 44,44 \% dan pada siklus II diperoleh hasil rata - rata 81,11 dengan persentase ketuntasan klasikal $100 \%$

\section{REFERENSI}

Ardi, A. Ma, Bahrudin (2013). Penerapan Metode Inkuiri Untuk Meningkatkan Kualitas

Pembelajaran IPA Pada Siswa Kelas V Sdn 5 Mayonglor Kabupaten Jepara.

Ayu Lestari. Fitriani, (2014) Upaya Meningkatkan Hasil Belajar IPA dengan

Menggunakan Metode Eksperimen Pada Peserta Didik Kelas V MIN Selat Hulu

Kuala Kapuas.

Depdiknas. (2003). Undang-undang Republik Indonesia No.23, tentang Sistem Pendidikan

Nasional. Jakarta: Biro Hukum dan Organisai Sekjend Depdiknas.

Dimyati dan Mudjiono. (2015). Belajar dan Pembelajaran. Jakarta: Rineka Cipta 
Pedagogik Jurnal Pendidikan, Maret 2017, Volume 12 Nomor 1, (27-33)

Jalil, Jasman (2014), Panduan Mudah Penelitian Tindakan Kelas (PTK), Jakarta Prestasi Pusat Karya (Group Relasi Inti Media)

Mira.(2015), Upaya Meningkatkan Hasil Belajar IPA Dengan Menggunakan Pendekatan Saintifik pada Peserta Didik Kelas V SDS Muhammadiyah Plus Kabupaten Kapuas Tahun Pelajaran 2014/2015.

Mularsih, Heni. (2010), Strategi Pembelajaran, Tipe Kepribadian dan Hasil Belajar Bahasa Indonesia pada Siswa Sekolah Menengah Pertama.

Ratna Sari. Selvi, (2013) Upaya Peningkatan Hasil Belajar Peserta Didik Melalui Metode Demonstrasi Mata Pelajaran IPA Pada SDN-9 Menteng Palangkaraya Tahun Pelajaran 2012/2013.

Risnawati. Elza Firanda dan Ani Widayanti, (2012). Model Aktif Learning dengan Teknik Learning Start Whit A Question dalam meningkatkan keaktifan peserta didik pada pembelajaran Akuntansi kelas IX Ilmu Sosial 1 SMA Negri 7 Yogyakarta Tahun Ajaran 2011/2012.

Selberman, Melvin L. (2005), Active Learning (101 Strategi Pembelajaran Aktif),

Yogyakarta Yappendis.

Sugiyono.(2013).Metode Penelitian Manajemen, Bandung : Alfabeta, CV

Susanto, M.Pd. Dr. Ahmad, (2012) Teori Belajar \& Pembelajaran di Sekolah Dasar, Jakarta Prenadamedia Group.

Tim, (2013), Buku Pedoman Penulisan Skripsi, Palangka Raya : Fakultas Keguruan dan Ilmu Pendidikan Universitas Muhammadiyah Palangkaraya.

Widyaningsih, Fitria (2013). Peningkatan Kualitaspembelajaran PKn Melalui Model Start Learning By Exchange Greetings And Questions (LEGQ) Berbasis Media Flash card pada Siswa Kelas V SDN Gunungpati 02 Semarang. 